\title{
Electrochemical DNA biosensor for detection of pork (Sus scrofa) using screen printed carbon-reduced graphene oxide electrode
}

\author{
Yeni W. Hartati ${ }^{\mathrm{a}}$, Tia A. Setiawati ${ }^{\mathrm{a}}$, Titin Sofyatin ${ }^{\mathrm{a}}$, Fitrilawati Fitrilawati ${ }^{\mathrm{b}}$, Anni Anggraeni ${ }^{\mathrm{a}}$, \\ Shabarni Gaffar ${ }^{\mathrm{a}, *}$ \\ ${ }^{a}$ Department of Chemistry, Faculty of Mathematics and Natural Science, Universitas Padjadjaran, \\ Jatinangor, West Java 43653 Indonesia \\ b Department of Physics, Faculty of Mathematics and Natural Science, Universitas Padjadjaran, \\ Jatinangor, West Java 43653 Indonesia
}

*Corresponding author, e-mail: shabarni.gaffar@unpad.ac.id

Received 13 May 2019

Accepted 4 Feb 2020

\begin{abstract}
The identification of pork in foodstuff is critical regarding the counterfeiting of meat and kosherness, which is a particular concern for certain religions. In this study, we developed an electrochemical detection method of pork DNA without the use of DNA amplification by using screen printed carbon-reduced graphene oxide (SPC-RGO) electrode. The probe DNA of CytB gene of $S$. scrofa mtDNA was immobilized on the SPC-RGO surface by passive adsorption. Differential pulse voltammetry (DPV) was used to characterise the probe-target DNA hybridisation based on the target's guanine oxidation signal. The Placket-Burman and Box Behnken designs were used to select the factors that influence the hybridisation of probe-target DNA and to optimise each parameter. The following findings regarding the several factors that influence the hybridisation process and optimum condition were obtained: $5.0 \mu \mathrm{g} / \mathrm{ml}$ of probe DNA, $6.0 \mathrm{~min}$ of immobilisation time of probe DNA, $20.0 \mathrm{~min}$ of probe-target hybridisation time, a scan rate at $0.5 \mathrm{~V} / \mathrm{s}$, the pulse amplitude at $50.0 \mathrm{mV}$, and the washing time of the electrode being as long as $40 \mathrm{~s}$. The limit of detection was obtained at $1.76 \mu \mathrm{g} / \mathrm{ml}$ for the linear range of $0-10.0 \mu \mathrm{g} / \mathrm{ml}$ target DNA while the relative standard deviation (RSD) was $2.25 \%$. The DNA biosensor was tested on the isolated DNA samples from pork, chicken and beef while the voltammetry response reveals that it can distinguish the samples. These results indicate that the proposed electrochemical DNA biosensor has the potential to develop the detection method of pork content in the food samples.
\end{abstract}

KEYWORDS: DNA biosensor, pork, voltammetry, SPC-RGO electrode

\section{INTRODUCTION}

The adulteration or preparation of meat products by mixing meats with cheaper meats of different species sources has been commonly practiced in many countries. Today, consumers demand highquality food products with the appropriate labeling of ingredients for various reasons, including medical motives, personal preferences (e.g., vegetarians) or religious prohibitions such as for Jews and Muslims. Rising consumer demand underscores the need for the development of more swift and reliable methods to identify species in food commodities such as detecting pork in food. On this note, instead of protein, a DNA analysis would be preferable to identify species due to the nature of protein being easily denaturised while processing [1-4].

DNA-based methods have become a consid- eration for researchers, managers and regulators. This method involves the detection, identification, quantification and monitoring of the falsification of species in raw and processed meat [5]. There are several detection and quantification methods for the identification of pork in food products that rely on DNA-based analyses. The polymerase chain reaction (PCR), real-time PCR, PCR-restricted fragment length polymorphism (PCR-RFLP), real-timemultiplex PCR, and species-specific PCR were used extensively $[3,4,6]$. Most recently, duplex droplet digital PCR has become more frequently used in identifying fraudulent meat products $[7,8]$.

There are numerous advantages to DNA-based analysis, including its rapidity, sensibility, simplicity and capacity for widespread speculation on the future availability of inexpensive and accurate means for identifying and quantifying each declared or 
undeclared component in finished commercial products [5,9]. Recent developed DNA-based methods include DNA sensors, DNA biochips and DNA microarray technology. These methods constitute a modern approach that enables the examination of complex mixtures of PCR products and may potentially identify a wide array of species simultaneously $[5,10,11]$.

A modified gold nanoparticle's DNA biosensor with citric acid-tannic was utilised for porcine detection in mixed meat spectroscopically. The visual change was rapid and the species detection was performed within ten minutes without any instrument. However, the method was solely qualitative, and the detection limit of 4-6 $\mu \mathrm{g} / \mathrm{ml}$ was considerably higher than conventional and real-time PCR [12, 13]. A chemiluminescent optical fibre genosensor was also developed for the detection of pork meat, which can detect a $1 \%$ quantity in mixture samples [14]. The new electrochemical DNA biosensor based on the bioconjugate of gold nanoparticlesDNA biosensor has also been reported, which was selective towards $10 \%$ of the pork DNA in the mixture [15].

The DNA-based electrochemical biosensor has gained attraction due to its simplicity, sensitivity, selectivity, and economical equipment. The use of graphene as a transducer in several electrochemical DNA biosensor studies has been successfully developed due to its unique feature. Graphene (or graphene oxide) is an excellent material as an anchor for biomolecular detection because of its large surface area (theoretically $2630 \mathrm{~m}^{2} / \mathrm{g}$ ) and unique sp2 (sp2/sp3) bond [16]. Based on the differences of binding affinity of single-stranded DNA (ssDNA) and double-stranded DNA (dsDNA) to the graphene layer, graphene has been successfully adopted as a means of distinguishing DNA strands [17]. Graphene has a larger surface area with better electrical conductivity than a glassy carbon electrode and is suitable for use as a sensing medium [18].

The application of experimental design for the detection of pork by electrochemical DNA biosensors has never been previously reported. PlacketBurman (PB) design and Box-Behnken (BB) response surface methodology has, on the other hand, been successfully applied in various experimental designs with complex design parameters involving two or more parameters by producing robust design models. Herein, we report a voltammetric DNA biosensor for pork detection based on the guanine oxidation signal of target DNA using SPC-RGO elec- trodes, and the application of $\mathrm{PB}$ and $\mathrm{BB}$ design experiments to obtain optimised parameters. The scheme of SPC-RGO DNA biosensor is indicated in Fig. 1.

\section{MATERIALS AND METHODS}

\section{Materials}

The DNA probe used in this study was based on Ref. [13]. Twenty nucleotide swine specific probe of CytB S. scrofa mtDNA nucleotide between 567 and 586: 5'-TACCICCCTCICAICCITAC$3^{\prime}$ (guanine base was substituted with inosine). The target DNA complementary sequences: 5'-GTACGGCTGCGAGGGCGGTA-3'. The oligonucleotide sequence was synthesised by IDT (Integrated DNA Technologies Pte. Ltd. Singapore). Commercial graphene oxide (GO) (Graphenea SA ES A7502260) was re-dispersed with redistilled water, $\mathrm{NaCl}, \mathrm{K}_{3}\left[\mathrm{Fe}(\mathrm{CN})_{6}\right]$ and acetic buffer saline (ABS), while phosphate buffer saline (PBS) was purchased from Merck (Germany). DNeasy Mericon Food (Qiagen, Cat. 3695140) and restriction enzyme Sal1 (R0138S) came from New England Biolabs (USA) while the SPCEs (Cat. DRP 110) were from Dropsens (Germany).

\section{Apparatus}

Cyclic voltammetry (CV) and differential pulse voltammetry (DPV) measurements were conducted using transducer Metrohm ${ }^{\circledR} \mu$ Autolab Type III Potentiostat/Galvanostat with NOVA 1.10 software (Metrohm, Switzerland). A pH meter (Mettler Toledo InLab pH combination polymer electrodes), microcentrifuge (Thermo Scientific MicroCL 17R, USA), BDA digital compact gel documentation system, a multi-mode reader (Tecan Infinite M200 PRO, Switzerland) and an UV Biophotometer Eppendorf (Germany) were also used. Finally, DESIGNEXPERT software version 9.1 (Stat ease Inc., USA) was used for processing data of $\mathrm{PB}$ and $\mathrm{BB}$ design.

\section{Modification of SPCE with GO and electrochemical characterisation}

The SPCE was modified with three different concentrations of GO: SPC modified with $1000 \mu \mathrm{g} / \mathrm{ml}$ of GO (SPC-RGO 1000), SPC-RGO 500 and SPCRGO 500 with $0.25 \mathrm{M} \mathrm{NaCl}$. Briefly, $40.0 \mu \mathrm{l}$ of GO (that was already sonicated for $15 \mathrm{~min}$ ) was dropped onto the SPCE, respectively. The GO was electro-deposited on SPCE and characterised by cyclic voltammetry (CV) by observing the redox activity of the electroactive species 


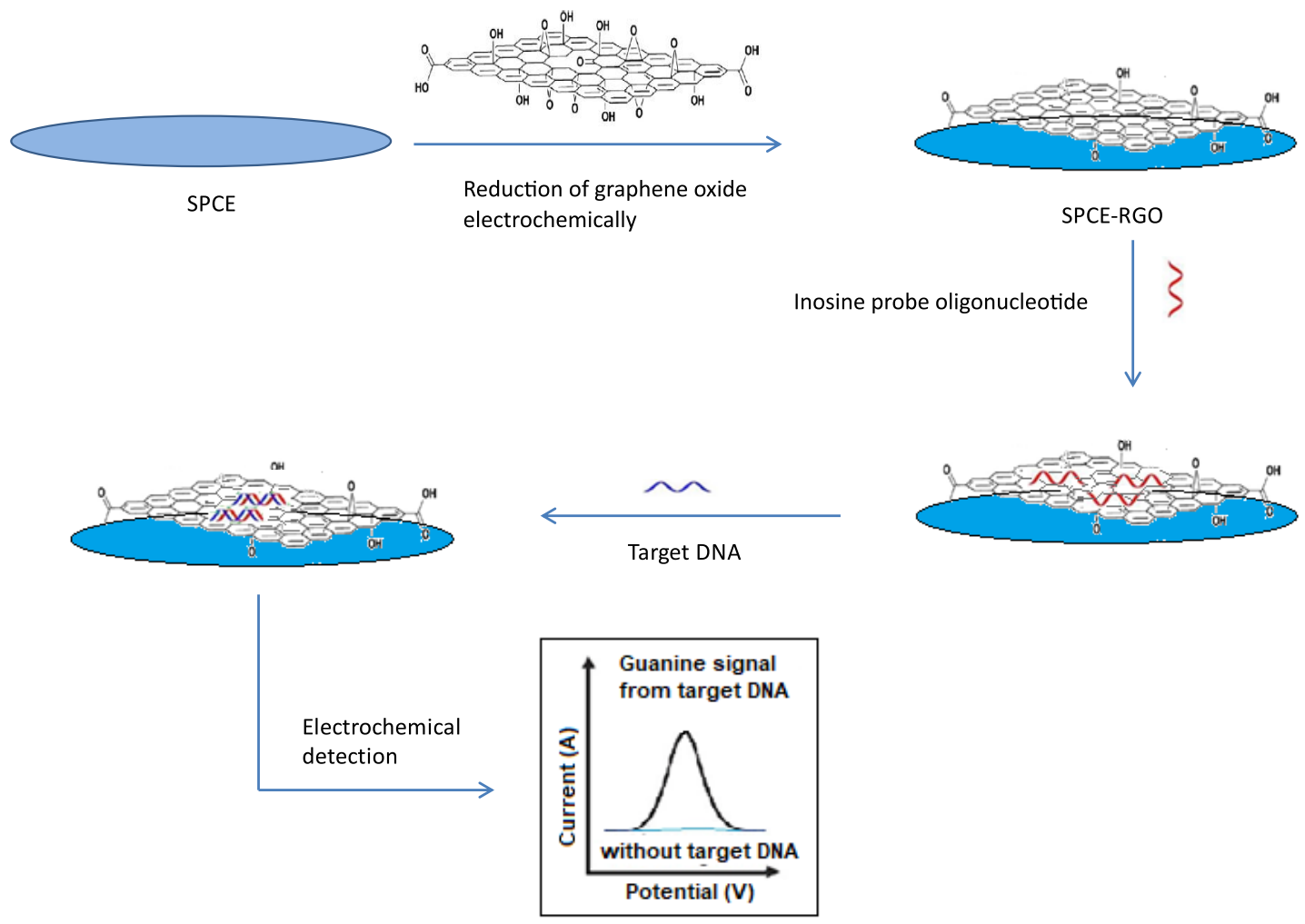

Fig. 1 The scheme of the SPC-RGO based pig DNA biosensor. The presence of target DNA (black) and the absence of target DNA can be distinguished by a differential pulse voltammetry signal.

$\left[\mathrm{Fe}(\mathrm{CN})_{6}\right]^{3-} /\left[\mathrm{Fe}(\mathrm{CN})_{6}\right]^{4-}$ using $10 \mathrm{mM} \mathrm{K}_{3}\left[\mathrm{Fe}(\mathrm{CN})_{6}\right]$ containing $100 \mathrm{mM}$ of $\mathrm{KCl}$. The $\mathrm{CV}$ was done for seven cycles at a potential range at -1.6 to $+0.4 \mathrm{~V}$ for $120 \mathrm{~s}$, at a frequency $50 \mathrm{~Hz}$, amplitude $0.04 \mathrm{~V}$ and voltage step at $0.004 \mathrm{~V}$ [20].

\section{Immobilisation of the probe DNA and} hybridisation of probe DNA-target DNA

The probe DNA (30 $\mu \mathrm{l}$ of $5.0 \mu \mathrm{g} / \mathrm{ml}$, diluted in ABS pH 5.0) was dropped onto SPC-RGO and incubated for $6 \mathrm{~min}$ at room temperature. It was washed with ABS pH 5.0 for $40 \mathrm{~s}$. Afterwards, $\mathrm{x} \mu \mathrm{l}$ of $\mathrm{y} \mu \mathrm{g} / \mathrm{ml}$ of the target DNA ( $\mathrm{x}$ and $\mathrm{y}$ were based on experimental design) (diluted in PBS pH 7.2) was dripped onto SPC-RGO-probe DNA, followed by incubation for 20 min and then washed with PBS pH 7.2 for $40 \mathrm{~s}$. After this process, the target DNA was hybridised to the probe DNA.

\section{Voltammetric analysis of biosensor DNA}

The probe DNA on SPCE-RGO was hybridised with various concentrations of synthetic target DNA $(0-10 \mathrm{ppm})$. The measurement was done at the optimum condition obtained by differential pulsed voltammetry analysis at the potential range from $+0.5 \mathrm{~V}$ to $+1.5 \mathrm{~V}$ in $0.1 \mathrm{M}$ phosphate buffer solution $\mathrm{pH}$ 7.0. The DPV peak current was measured based on the guanine oxidation signal of the target DNA, which was hybridised to the cytosine in the probe DNA sequence. The guanine in the probe DNA sequence was substituted with the inosine, which does not show peak current in the range $-1 \mathrm{~V}$ to $+1.5 \mathrm{~V}$. The limit of detection was calculated by measuring the average of blank responses, plus three times the standard deviation of the blank response.

\section{Determination of optimum experimental condition}

Determination of optimum experimental conditions was carried out using the factorial RSM Box-Behnken design level $-1,0$, and +1 using Minitab 17 statistical software. Eleven factors (XI) were screened by applying $\mathrm{PB}$, including $\mathrm{GO}$ concentration (A), probe DNA concentration (B), time to immobilise probe DNA (C), time to hybridise probe-target DNA (D), the scan rate (E), pulse amplitude (F), the number of CV cycles (G), the $\mathrm{pH}$ buffer of probe DNA (H), pH buffer of target 
DNA $(\mathrm{J})$, the washing time $(\mathrm{K})$, and pretreatment of electrode (L). The selected factors from the $\mathrm{PB}$ design were optimised by the Box-Behnken (BB) experiment design. The analytical parameters were then determined using the optimum condition of the $\mathrm{BB}$ results. The linearity range was determined by examining various concentrations of target DNA $(0-10 \mu \mathrm{g} / \mathrm{ml})$. Furthermore, the biosensor response was measured using the DPV at the potential range of $+0.5 \mathrm{~V}$ to $+1.5 \mathrm{~V}$ in a $0.1 \mathrm{M}$ of phosphate buffer $\mathrm{pH} 7$.

DNA extraction and application of voltammetric DNA biosensor for the detection of meat sample

Approximately $20 \mathrm{mg}$ of mashed pork, beef, and chicken meat samples were weighed and placed into a $1.5-\mathrm{ml}$ microtube. The total DNA was isolated following the procedures in the DNeasy Mericon food kit (Qiagen). The isolated DNA was then analysed by electrophoresis on $1 \%$ agarose gel (the data were not shown) and quantified using a UV spectrophotometer. The isolated DNA was cut with the Sal1 restriction enzyme to linearise the mtDNA following the procedure. The DNA concentration was measured by Biophotometer UV at $260 \mathrm{~nm}$.

The purity of the DNA was then determined to calculate the ratio of absorbance at $260 / 280$. The DNA samples were diluted five times to a total volume of $50 \mu \mathrm{l}$. DNA samples were denatured by heating at $95^{\circ} \mathrm{C}$ for $5 \mathrm{~min}$ and $20 \mu \mathrm{l}$ of DNA samples were dropped onto the SPC-RGO-DNA probe to be incubated for $1 \mathrm{~h}$, followed by rinsing with $0.05 \mathrm{M}$ phosphate buffer $\mathrm{pH}$ 7.0. The biosensor response was measured using DPV at the potential range $-0.45 \mathrm{~V}$ to $+0.1 \mathrm{~V}$.

\section{RESULTS AND DISCUSSION}

\section{SPCE modification and cyclic voltammetry characterisation}

The SPCE was modified with three different concentrations of GO: SPC modified with $1000 \mu \mathrm{g} / \mathrm{ml}$ of GO (SPC-RGO 1000), SPC-RGO 500, and SPCRGO 500 with $0.25 \mathrm{M}$ of $\mathrm{NaCl}$. Fig. 2 depicts the characterisation of the SPC-RGO using the ferric cyanide redox system by CV. The SPC-RGO 1000 showed a higher current response compared to other modifications. The success of electrodeposition and reduction of the graphene oxide in the solution were dependent on the average conductivity. The optimum conductivity of GO was about 4$25 \mathrm{mS} / \mathrm{cm}$ available from $500 \mu \mathrm{g} / \mathrm{ml}$ of GO:0.25 M $\mathrm{NaCl}(1: 1)$ [21].

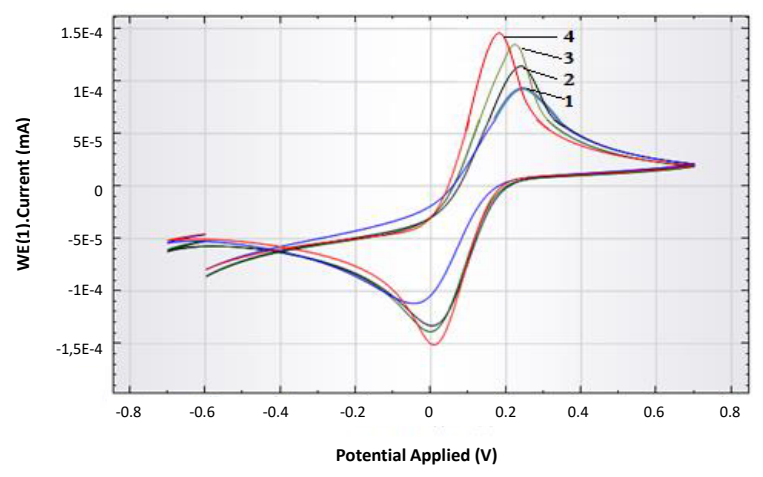

Fig. 2 Cyclic voltammogram of $\mathrm{K}_{3}\left[\mathrm{Fe}(\mathrm{CN})_{6}\right]$ containing $100 \mathrm{mM}$ of $\mathrm{KCl}$ on SPCE with and without RGO modification; (1) SPCE without modification, (2) SPCE with 1000 ppm of GO-Na+ ${ }^{+}$, (3) SPCE with 500 ppm of GO-Na ${ }^{+}$, and (4) SPCE with 1000 ppm of GO-Na ${ }^{+}$.

Fig. 2 also shows that the modification of SPCE with GO affects the current response because the GO increases the surface area of the electrode. The peak current generated by SPC-RGO 1000 was 2.3-times higher compared to that without GO modification. The electron transfer from the ferric cyanide redox system became easier on the SPC-RGO surface than SPC without GO electrodes.

\section{Screening of significant factors and optimisation of experimental condition}

The probe DNA used in this study was $20 \mathrm{nu}-$ cleotides within the CytB gene of $S$. scrofa mtDNA. The CytB gene was used because it has low homology to the sequence of other species while mtDNA is present in high evolutionary values in abundant amounts of copy. The mtDNA genes were also protected from degradation attacks due to their protective mitochondrion forms and sizes [5].

The immobilisation of probe DNA onto SPCRGO electrodes occurs due to the strong adsorption of the ssDNA strand on GO shown by high fluorescence quenching efficiency of GO [22]. These passive adsorptions would immobilise the biomolecules onto the electrodes by utilising hydrophobic, hydrophilic and other physical interactions.

The screening of factors that influence the experiment using the PB design was obtained via the Randles-Sevic equation for voltammetry analysis. The GO concentrations were chosen between 1000 and $4000 \mathrm{ppm}$ based on previous research [23]. DNA probe concentrations were between 5 and 20 ppm based on the effectiveness of DNA concentration on the surface of the graphite electrode [24]. 
The immobilisation and hybridisation time was chosen between 5 and $20 \mathrm{~min}$ based on previous research for the effectiveness of the analysis period [24]. The lowest and highest values of voltammetry parameters as scan rate, pulse amplitude and cycle number were chosen based on the effectiveness of the deposition of GO onto SPCE. The $\mathrm{pH}$ and washing time for experiment optimisation and pre-treatment was done to make SPC-RGO more positively so that it can absorb negative phosphate groups from DNA [24].

The calculation of regression coefficients is initiated upon a collection of 12 PB design runs and calculated responses. The results were interpreted using the first-degree polynomial model, which can be presented in the following equation:

$$
\begin{aligned}
Y= & 0.8317-0.3533 \mathrm{~A}+0.2367 \mathrm{~B}+0.2217 \mathrm{C} \\
& +0.4911 \mathrm{D}-0.3800 \mathrm{E}-0.0500 \mathrm{~F}-0.2167 \mathrm{G} \\
& +0.0172 \mathrm{H}-0.2033 \mathrm{~J}+0.4050 \mathrm{~K}+0.5384 \mathrm{~L} .
\end{aligned}
$$

This equation based on $Y=\beta_{0}+\cdots+\beta_{i} X_{i}$, where $Y$ is predicted response (the peak currents), $\beta$ is the intercept of mean, $X_{i}$ is the setting (A-L factors), and $\beta_{i}$ are the respective coefficients. An analysis of variance (ANOVA) was performed in order to determine which factors significantly affected the peak current. The ANOVA ( $F$-test) showed that the second model is well adjusted to the experimental data (the data were not shown).

The coefficient of variation indicates the degree of precision to which the treatments were compared. However, because the number of degrees of freedom for the error term is small in saturated designs, the power of classical ANOVA was too low [25]. For this reason, a graphical tool, the effect probability plot of the estimates, was used to identify possible significant effects and to estimate the standard deviation of the effects. Significant effects in normal plots are detected through visual inspection. A graphical representation of the significant effect probability is shown in Fig. 3 as generated by the software Design Expert 9.1 [26]. The vertical $Y$-axis shows the expected normal values for the respective values after they were ordered in rank while the effects are plotted along the horizontal $X$-axis. The slope of the line through the effects assumed to be non-significant gives an estimate of the standard deviation $(\sigma)$ of the error [25].

By using the effect probability plot in Fig. 3, we were able to identify 7 important factors of the experiment: the probe DNA concentration (B), immobilisation time (C), hybridisation time (D),

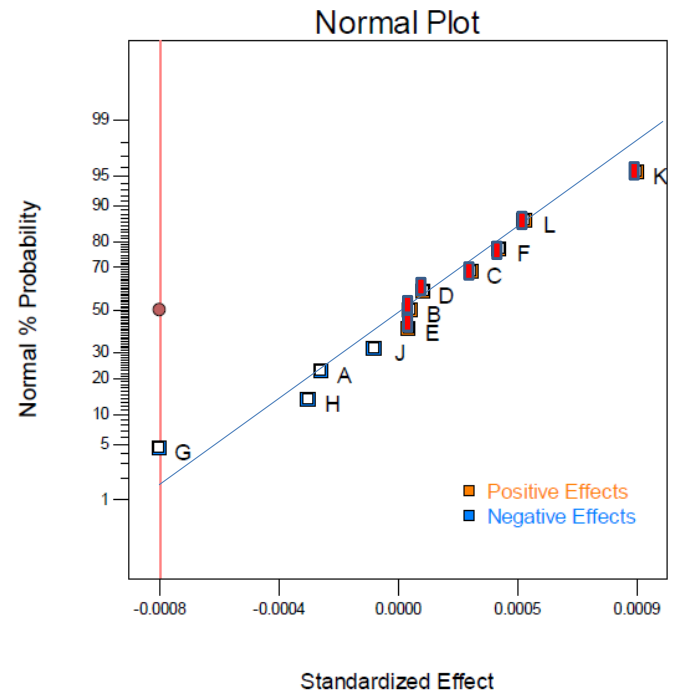

Fig. 3 Graphical representation of the significant effect probability in a normal plot of the estimates of pork DNA biosensor generated by the software program Design Expert 9.1.

Table 1 The optimisation of experimental conditions using Box-Behnken design with the independent variable values.

\begin{tabular}{lcrrr}
\hline \multirow{2}{*}{ Factor } & \multirow{2}{*}{ Unit } & \multicolumn{3}{c}{ Level } \\
\cline { 3 - 5 } & & \multicolumn{1}{c}{-1} & \multicolumn{1}{c}{0} & +1 \\
\hline B-probe DNA concentration & $\mu \mathrm{g} / \mathrm{ml}$ & 5.00 & 12.50 & 20.00 \\
C-immobilization time & $\mathrm{min}$ & 5.00 & 12.50 & 20.00 \\
D-hybridisation time & $\mathrm{min}$ & 5.00 & 12.50 & 20.00 \\
F-scan rate & $\mathrm{V} / \mathrm{s}$ & 0.50 & 0.85 & 1.20 \\
H-pulse amplitude & $\mathrm{mV}$ & 20.00 & 35.00 & 50.00 \\
K-washing time & $\mathrm{s}$ & 4.00 & 22.00 & 40.00 \\
\hline
\end{tabular}

scan rate $(\mathrm{F})$, pulse amplitude $(\mathrm{H})$, washing time of electrode $(\mathrm{K})$, and the pretreatment of the electrode (L). These important factors are marked with red squares in the plot (Fig. 3).

Based on the PB design result shown in Fig. 3, 7 variables were chosen for further optimisation by using the $\mathrm{BB}$ design, excepting pretreatment of the electrode because it was one of the most important factors. Therefore, all experiments were conducted with the pretreatment of the electrode. The experiment consisted of 48 experimental runs (data were not shown) to optimise the peak current as the responses. Table 1 presents the experimental BB design with independent variable values. All experiments were carried out in duplicate, and the mean value was taken as the response for the $\mathrm{BB}$ design. The level of $-1,0$, and +1 presented the lowest, medium and the highest figure of each 
parameter.

By using the ANOVA, the statistical significance of each coefficient of regression equation was checked by Fischer's value ( $F$-value) and probability value ( $p$-value) which, in turn, indicate the interactions of the variables. The $F$-value and the $p$-value obtained were 2.66 and 0.0286 , respectively. The large $F$-value 2.66 indicates the significance of the term. This model was also significant with a $p$-value of 0.0286 , which meant that only $2.86 \%$ of the data occurs in noise. Optimisation was then performed to search for the values of different independent variables that were considered optimal, effective and efficient to achieve the desired result [25,27]. The optimisation process often involves a single response; in this research, the expected response was obtained through the maximum current response.

Based on data processing, immense desirability value was also obtained, which was 0.558 and used as the optimum value of the process. The value of desirability lies between 0 and 1 , which describes the proximity of the response to the ideal amount. If the response lies at an unacceptable interval, the value of desirability is 0 . Moreover, if the response is at a range reaching the ideal value, desirability is 1.0. The response between the tolerance intervals is that of desirability 0 and 1 [29]. The optimisation goal is not to obtain a desirability value of 1.0 , but to find the best conditions that bring together all the functions.

The optimum condition of experiments with the highest desirability value were as follows: $\mathrm{B}=$ probe DNA concentration $(5.00 \mu \mathrm{g} / \mathrm{ml}), \mathrm{C}=$ immobilisation time $(6.0 \mathrm{~min}), \mathrm{D}=$ hybridisation time (20.0 min), $\mathrm{F}=$ scan rate $(0.5 \mathrm{~V} / \mathrm{s}), \mathrm{H}=$ pulse amplitude $(50.0 \mathrm{mV}), \mathrm{K}=$ washing time $(40.0 \mathrm{~s})$. The peak current of $1.72(\mu \mathrm{A})$ was then obtained as the optimum condition of experiments (the data were not shown).

\section{Voltammetric measurement of the target DNA based on Box-Behnken optimisation}

Fig. 4 shows the peak current linearity of the target DNA with various concentrations under optimum conditions. The linear relationship between target DNA concentration and the peak current of the Guanine oxidation was I $(\mu \mathrm{A})=0.2068$ [target DNA $]+0.0622$ while the $R^{2}$ value was 0.9836 .

After determining the range of confidence in the intercept for finding out whether there is a systematic error in the measurements, the intercept confidence range was calculated with a $95 \%$ confidence level between -0.2044 to 0.3287 . The

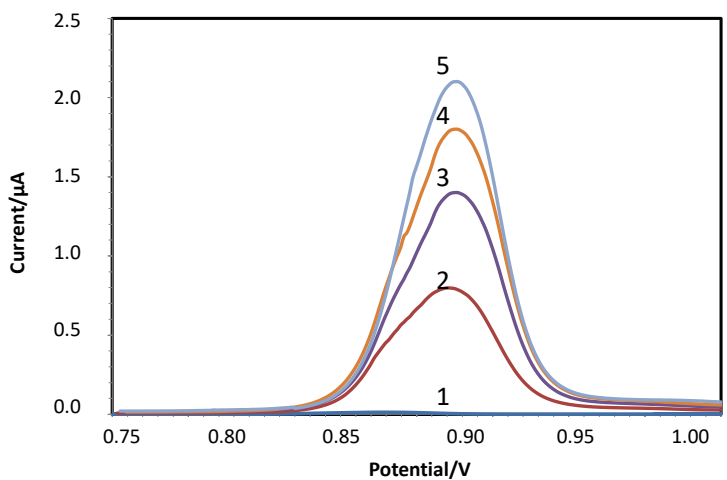

Fig. 4 Differential pulse voltammograms for $5.0 \mu \mathrm{g} / \mathrm{ml}$ of probe DNA with various concentrations of synthetic target DNA. Scanning using the DPV technique at a potential range of 0.5-1.5 V. (1) $0 \mathrm{ppm}$; (2) $4.0 \mathrm{ppm}$; (3) $6.0 \mathrm{ppm}$; (4) $8.0 \mathrm{ppm}$; and (5) $10.0 \mathrm{ppm}$.

Table 2 Comparison of the limit of detection using biosensor methods.

\begin{tabular}{|c|c|c|c|}
\hline Method & $\begin{array}{c}\text { LoD } \\
(\mu \mathrm{g} / \mathrm{ml})\end{array}$ & $\begin{array}{c}\text { Range } \\
(\mu \mathrm{g} / \mathrm{ml})\end{array}$ & Ref. \\
\hline $\begin{array}{l}\text { Colorimetric gold nanoparticle } \\
\text { sensor (1) }\end{array}$ & 4.00 & $0.4-6.0$ & {$[12]$} \\
\hline $\begin{array}{l}\text { Colorimetric gold nanoparticle } \\
\text { sensor (2) }\end{array}$ & 6.00 & $0.3-9.0$ & {$[13]$} \\
\hline $\begin{array}{l}\text { Chemiluminescent optical } \\
\text { fibre genosensor }\end{array}$ & 2.00 & $1.0-7.5$ & [14] \\
\hline $\begin{array}{l}\text { Bioconjugate electrochemical } \\
\text { biosensor }\end{array}$ & 0.58 & $0.1-5.0$ & {$[15]$} \\
\hline $\begin{array}{l}\text { Graphene electrochemical } \\
\text { biosensor (this work) }\end{array}$ & 1.76 & $1.0-10.0$ & - \\
\hline
\end{tabular}

intercept value passed 0 points, following which the regression equation was adjusted to $Y=0.2148 X$. The slope of the equation was then used to calculate the limits of detection (LoD) and limit of quantitation (LoQ). By using the equation LoD $=3 S_{\mathrm{b}} / \mathrm{m}$, where $S_{\mathrm{b}}$ is the standard deviation of the blank, and $m$ is the slope of the equation, the detection limit of the measurement was obtained at a value of $1.76 \mathrm{ng} / \mu \mathrm{l}$. RSD for five times measurement of $10.0 \mu \mathrm{g} / \mathrm{ml}$ target DNA was $2.25 \%$.

The previous study shows that a gold nanoparticle-probe DNA bioconjugate based on electrochemical biosensor for detection of Sus scrofa mtDNA using methylene blue indicators [15] had a lower detection limit than this study. Nevertheless, this proposed method has the advantage of being simpler. Its simplicity is found in the immobilisation system only by simple adsorption with the detection 


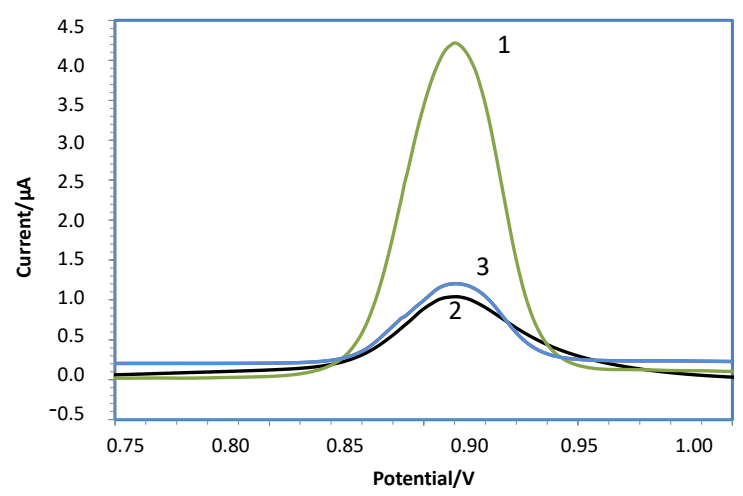

Fig. 5 Differential pulse voltammograms of $5.0 \mu \mathrm{g} / \mathrm{ml}$ of probe DNA with a variety of target DNA samples: (1) pig DNA; (2) chicken DNA; and (3) cow DNA. Scanning was carried out by using the DPV technique at a potential range of $0.5-1.5 \mathrm{~V}$.

of hybridisation based on the target's internal base electroactive properties.

Guanine is the most electroactive part of the DNA molecule. The substitution of guanine in the probe's DNA sequences with inosine enables the detection of the guanine oxidation in the target DNA. This label-free electrochemical detection has eliminated the external labels or indicators and significantly shortened the assay time, hence increasing interest [24, 30-32].

The comparison of the analytical performance of the proposed DNA biosensor with previous biosensor research is shown in Table 2. It can be concluded that, based on the detection limit, the proposed method can be used as an alternative to determine DNA in raw meat samples in a simple way.

\section{Application of voltammetric DNA biosensor for the detection of meat sample}

The isolated mtDNA from pork, chicken, and beef meat were characterised by electrophoresis and the spectrophotometer (data were not shown). The UV absorption measured the quantity and purity of DNA at a wavelength of $260 \mathrm{~nm}$ and $280 \mathrm{~nm}$. The absorption ratio of A260:A280 was 1.85, indicating that the isolated DNA was pure or not contaminated with a protein. The DNA was then cut using a Sal1 restriction enzyme to linearise the mtDNA. Restricted DNA was used to determine the response and selectivity of the electrochemical DNA biosensor.

Voltammograms of guanine oxidation signal generated from the hybridisation of probe-sample DNA (pig, chicken, and cow DNA) were shown in Fig. 5. The result shows that the peak current signal of the hybridised probe-pork mtDNA sample is four-time higher compared to that of chicken and beef samples. The chicken and beef mtDNA will not hybridise with the probe DNA because it does not contain a complement base of the probe sequence. However, there might be several base pairs of sequence matches. Therefore, the current responses were observed, but lower. The difference in peak current height can then be used to ensure that the sample contains pig DNA.

\section{CONCLUSION}

Based on the selected factors and optimisation with Placket-Burman and Box-Behnken experiment design, the voltammetric DNA biosensor using SPCRGO can be used to detect pig DNA in raw sample. The factors affecting the experiments were probe DNA concentration, the immobilisation time of probe DNA, the hybridisation time of probe-target DNA, the scan rate, pulse amplitude, washing time and pre-treatment of electrodes. The importance of this study will serve as a baseline for developing other alternative methods for monitoring food adulteration, especially for kosher or halal meat.

Acknowledgements: Universitas Padjadjaran Competence of Lecturer Research supported this paper, No. 872/UN6.3.1/LT/2017, awarded to Dra. Titin Sofyatin, M.Si.

\section{REFERENCES}

1. Calvo JH, Zaragoza P, Osta R (2001) Technical note: A quick and more sensitive method to identify pork in processed and unprocessed food by PCR amplification of a new specific DNA fragment. J Anim Sci 79, 2108-2112.

2. Cai Y, He Y, Lv R, Chen H, Wang Q, Pan L (2017) Detection and quantification of beef and pork materials in meat products by duplex droplet digital PCR. PLoS One 12, ID e0181949.

3. Ha J, Kim S, Lee J, Lee $\mathrm{S}$, Lee $\mathrm{H}$, Choi $\mathrm{Y}$, Oh $\mathrm{H}$, Yoon Y (2017) Identification of pork adulteration in processed meat products using the developed mitochondrial DNA-based primers. Korean $J$ Food Sci Anim Resour 37, 464-468.

4. Karabasanavar NS, Singh SP, Kumar D, Shebannavar SN (2014) Detection of pork adulteration by highlyspecific PCR assay of mitochondrial D-loop. Food Chem 145, 530-534.

5. Ali ME, Kashif M, Kamal U, Hashim U, Mustafa S, Man YBC (2011) Species authentication methods in 
foods and feeds: the present, past, and future of halal forensics. Food Anal Method 5, 935-955.

6. Köppel R, Ruf J, Rentsch J (2011) Multiplex real-time PCR for the detection and quantification of DNA from beef, pork, horse and sheep. Euro Food Res Technol 232, 151-155.

7. Ali ME, Hashim U, Dhahi TS, Mustafa S, Che Man YB (2011) Analysis of pork adulteration in commercial burgers targeting porcine-specific mitochondrial cytochrome $b$ gene by TaqMan probe real-time polymerase chain reaction. Food Anal Method 5, 784-794.

8. Yusop MHM, Mustafa S, Man YBC, Omar AR, Mokhtar NFK (2012) Detection of raw pork targeting porcine-specific mitochondrial cytochrome B gene by molecular beacon probe real-time polymerase chain reaction. Food Anal Method 5, 422-429.

9. Darling J, Blum M (2007) DNA-based methods for monitoring invasive species: a review and prospectus. Biol Invasions 9, 751-765.

10. Teletchea F (2009) Molecular identification methods of fish species: reassessment and possible applications. Rev Fish Biol Fisher 19, 265-293.

11. Iwobi A, Huber I, Hauner G, Miller A, Busch U (2011) Biochip technology for the detection of animal species in meat products. Food Anal Method 4, 389-398.

12. Ali ME, Hashim U, Mustafa S, Che Man YB, Yusop MHM, Bari MF, Islam KN, Hasan MF (2011) Nanoparticle sensor for label free detection of swine DNA in mixed biological samples. Nanotechnol 22, ID 195503.

13. Ali ME, Hashim U, Mustafa S, Che Man YB, Islam KN (2012) Gold nanoparticle sensor for the visual detection of pork adulteration in meatball formulation. $J$ Nanomaterials 2012, 1-7.

14. Torelli E, Manzano M, Marks RS (2017) Chemiluminescent optical fibre genosensor for porcine meat detection. Sens Actuators B Chem 247, 868-874.

15. Hartati YW, Suryani AA, Agustina M, Gaffar S, Anggraeni A (2019) A gold nanoparticleâĂŞDNA bioconjugateâĂŞbased electrochemical biosensor for detection of Sus scrofa mtDNA in raw and processed meat. Food Anal Methods 12, 2591-2600.

16. Hu Y, Li F, Han D, Niu L (2015) Biocompatible Graphene for Bioanalytical Applications, Springer, Berlin.

17. He S, Song B, Li D, Zhu C, Qi W, Wen Y, Wang L, Song S, Fang H, Fan C (2010) A graphene nanoprobe for rapid, sensitive, and multicolor fluorescent DNA analysis. Adv Funct Mater 20, 453-459.

18. Wang Q, Zheng M, Shi J, Gao F, Gao F (2011) Electrochemical oxidation of native double-stranded DNA on a graphene-modified glassy carbon electrode. Electroanalysis 23, 915-920.

19. Ali ME, Hashim U, Kashif M, Mustafa S, Che Man YB, Abd Hamid S (2012) Development of swine-specific DNA markers for biosensor-based halal authentica- tion. Genet Mol Res 11, 1762-1772.

20. Kuswandi B, Cendekiawan K, Kristiningrum N, Ahmad M (2015) Pork adulteration in commercial meatballs determined by chemometric analysis of NIR Spectra. J Food Measure Character 9, 313-321.

21. Hilder M, Winther-jensen B, Li D, Macfarlane DR (2011) Direct electro-deposition of graphene from aqueous suspensions. Phys Chem 13, 9187-9193.

22. Lu C-H, Yang H-H, Zhu C-L, Chen X, Chen G-N (2009). A graphene platform for sensing biomolecules. Angew Chem Int 48, 1178-1271.

23. Pokpas K, Jahed N, Tovide O, Baker PG, Iwuoha EI (2014) Nafion-graphene nanocomposite in situ plated bismuth-film electrodes on pencil graphite substrates for the determination of trace heavy metals by anodic stripping voltammetry. Int $J$ Electrochem Sci 9, 5092-5115.

24. Hartati YW, Wyantuti S, Firdaus ML, Auliani N, Surbakti R, Gaffar S (2016) A rapid and sensitive diagnosis of typhoid fever based on nested PCRvoltammetric DNA biosensor using flagellin gene fragment. Indones J Chem. 16, 87-91.

25. Vanaja K, Shobha RH (2007) Design of experiments: concept and applications of Plackett Burman design. Clin Res Regul Aff 24, 1-23.

26. Kraber S (2013) How to Get Started with DesignExpert Software, available at: www.statease.com/ webinar.html

27. Islam MA, Sakkas V, Albanis TA (2009) Application of statistical design of experiment with desirability function for the removal of organophosphorus pesticide from aqueous solution by low-cost material. $J$ Hazard Mater 170, 230-238.

28. Chen F, Zhang Q, Fei S, Gu H, Yang L (2016) Optimization of ultrasonic circulating extraction of samara oil from Acer saccharum using combination of Plackett-Burman design and Box-Behnken design. Ultrason Sonochem 35, 161-175.

29. Raissi S, R-Eslami F (2009) Statistical process optimization through multi-response surface methodology. World Acad Sci Eng Technol 51, 267-271.

30. Erdem A, Pividori MI, Lermo A, BonanniA, Valle Md, Alegret S (2006) Genomagnetic assay based on label-free electrochemical detection using magnetocomposite electrodes. Sens Actuators B Chem 114, 591-598.

31. Nurmalasari R, Gaffar S, Hartati YW (2015) Labelfree electrochemical DNA biosensor for the detection of mycobacterium tuberculosis using gold electrode modified by self-assembled monolayer of thiol. Procedia Chem 17, 111-117.

32. Suryapratiwi WN, Paat VI, Gaffar S, Hartati YW (2017), DNA biosensor for detection of Salmonella typhi from blood sample of typhoid fever patient using gold electrode modified by self-assembled monolayers of thiols. AIP Conf Proc 1848, ID 030005. 